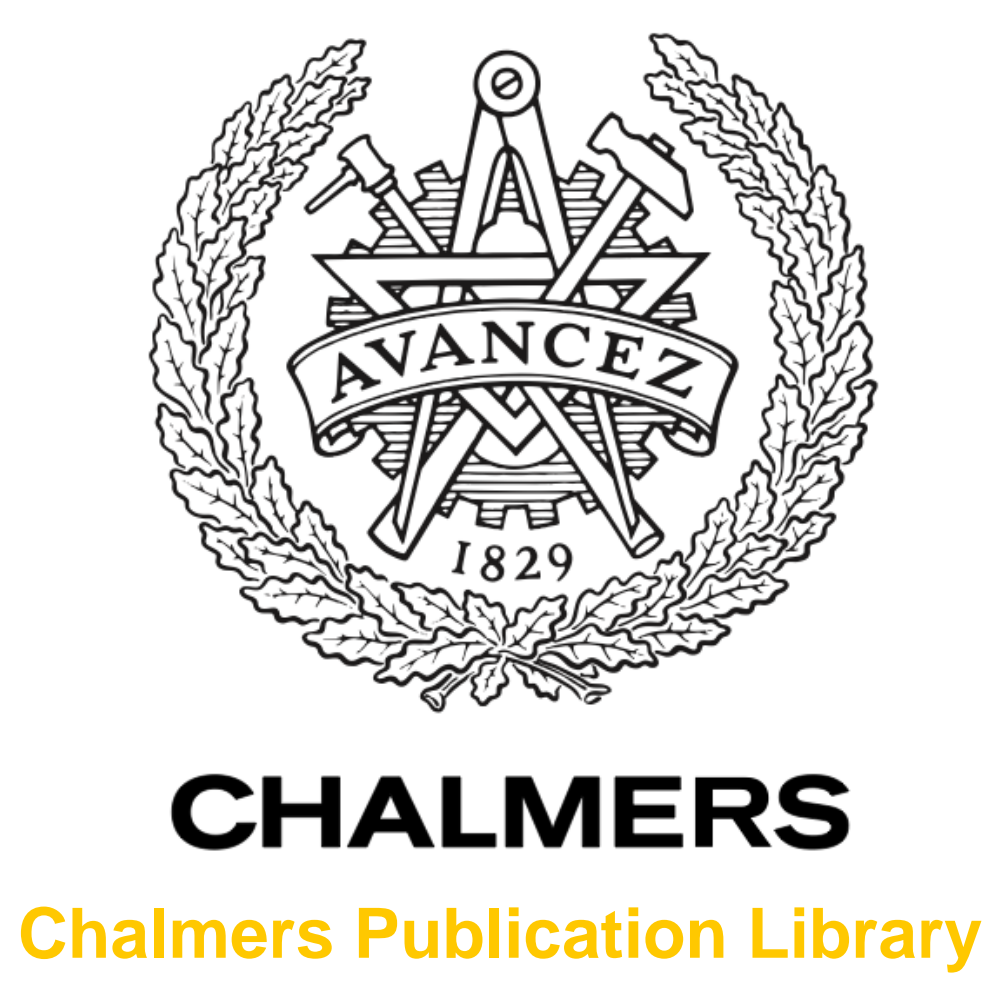

\title{
Emissions of nitrogen oxide from a circulating fluidized bed boiler--the influence of design parameters
}

This document has been downloaded from Chalmers Publication Library (CPL). It is the author's version of a work that was accepted for publication in:

\section{In Circulating Fluidized Bed Technology II, Proceedings of the Second International Conference on Circulating Fluidized Beds, Compiégne, France, 14-18 March 1988}

Citation for the published paper:

Åmand, L. ; Leckner, B. (1988) "Emissions of nitrogen oxide from a circulating fluidized bed boiler--the influence of design parameters". In Circulating Fluidized Bed Technology II, Proceedings of the Second International Conference on Circulating Fluidized Beds,

Compiégne, France, 14-18 March 1988

Downloaded from: http://publications.lib.chalmers.se/publication/238585

Notice: Changes introduced as a result of publishing processes such as copy-editing and formatting may not be reflected in this document. For a definitive version of this work, please refer to the published source. Please note that access to the published version might require a subscription. 


\title{
Circulating Fluidized Bed Technology II
}

Proceedings of the Second International Conference on

Circulating Fluidized Beds

Compiègne, France, 14-18 March 1988

\author{
Edited by \\ Prabir Basu \\ Centre for Energy Studies \\ Technical University of Nova Scotia \\ Halifax, Canada
}

and

Jean François Large

Department of Chemical Engineering Université de Technologie de Compiègne

Compiègne, France

\section{PERGAMON PRESS}

Oxford - New York - Beijing - Frankfurt

São Paulo • Sydney • Tokyo • Toronto 
U.K.

U.S.A.

PEOPLE'S REPUBLIC OF CHINA

FEDERAL REPUBLIC OF GERMANY

BRAZIL

AUSTRALIA

JAPAN

CANADA
Pergamon Press plc, Headington Hill Hall, Oxford OX3 0BW, England

Pergamon Press, Inc., Maxwell House, Fairview Park, Elmsford, New York 10523, U.S.A.

Pergamon Press, Room 4037, Qianmen Hotel, Beijing, People's Republic of China

Pergamon Press GmbH, Hammerweg 6,

D-6242 Kronberg, Federal Republic of Germany

Pergamon Editora Ltda, Rua Eça de Queiros, 346, CEP 04011, Paraiso, São Paulo, Brazil

Pergamon Press Australia Pty Ltd., P.O. Box 544, Potts Point, N.S.W. 2011, Australia

Pergamon Press, 5th Floor, Matsuoka Central Building, 1-7-1 Nishishinjuku, Shinjuku-ku, Tokyo 160, Japan

Pergamon Press Canada Ltd., Suite No. 271, 253 College Street, Toronto, Ontario, Canada M5T 1R5

Copyright (C) 1988 Pergamon Press plc

All Rights Reserved. No part of this publication may be reproduced, stored in a retrieval system or transmitted in any form or by any means: electronic, electrostatic, magnetic tape, mechanical, photocopying, recording or otherwise, without permission in writing from the publishers.

First edition 1988

\section{Library of Congress Cataloging-in-Publication Data}

International Conference on Circulating Fluidized Beds (2nd: 1988: Compiègne, France)

Circulating fluidized bed technology II:proceedings of the Second International Conference on Circulating Fluidized Beds, Compiègne, France, 14-18 March 1988/edited by Prabir Basu and Jean François Large.-1st ed. p. cm.

Sponsored by European Federation of Chemical Engineering, Société de chimie industrielle, and Ministère de la recherche et de l'enseignement supérieur.

1. Fluidization-Congresses. I. Basu, Prabir, 1946- II. Large, Jean Francois. III. European Federation of Chemical Engineering. IV. Société de chimie industrielle (France) V. France. Ministère de la recherche et de l'enseignement supérieur. VI. Title

TP156.F65I47 $1988 \quad 660.2^{\prime} 84292$-dc19 $88-22527$

\section{British Library Cataloguing in Publication Data}

International Conference on Circulating Fluidized Beds (2nd:1988: Compiègne, France)

Circulating fluidized bed technology 2 .

1. Fuels. Fluidised combustion

I. Title II. Basu, Prabir III. Large, Jean François $621.402^{\prime} 3$

ISBN: 0-08-036225-7 
2nd Int. Conf. on Circulating Fluidized Bed Boilers

Compiègne, March 1988

\title{
EMISSIONS OF NITROGEN OXIDE FROM A CIRCULATING FLUIDIZED BED BOILER - THE INFLUENCE OF DESIGN PARAMETERS
}

\author{
L-E. Åmand and B. Leckner \\ Department of Energy Conversion \\ Chalmers University of Technology \\ S-412 96 Göteborg, Sweden
}

\begin{abstract}
KEYWORDS
Nitrogen oxide emission, circulating fluidized bed boiler, air supply, primary and secondary air.
\end{abstract}

\section{INTRODUCTION}

The emissions of nitrogen oxides from fluidized bed boilers can be influenced in many ways. Fundamental knowledge about the mechanisms of the reduction of nitrogen oxides is available from laboratory investigations, but experience in translating this knowledge to combustors, especially to circulating fluidized bed boilers (CFBB), is scarce. A contribution in this direction was made by Hirama and co-workers (1987) who published results from a laboratory-scale circulating fluidized bed reactor. At the same time a study of the influence of the operating parameters on the NO emission from a $40 \mathrm{MW}$ commercial CFBB compared to a stationary fluidized bed boiler (SFBB) was presented by Leckner and Amand (1987).

The commercial CFBB used in the latter work proved to be suitably designed for the type of experiments made, but there were certain limitations. For instance, at a constant total excess air ratio, the ratio of primary and secondary air had to be varied in order to vary the temperature of the bed. Both of these parameters were suspected to have some influence on the NO emission. In order to resolve this co-variation of parameters, an existing CFBB of 8 MW thermal capacity was modified to permit independent variations of the bed temperature and the air supply. The present paper deals with some of the results hitherto obtained with the 8 MW boiler.

\section{THE BOILER}

The experimental 8 MW CFBB was designed and built by Götaverken Energy in 1981 . The features of the boiler are shown in Fig. 1 .

The height of the combustion chamber is $8.5 \mathrm{~m}$ and the cross-section is about $1.8 \mathrm{~m}^{2}$. The fluidizing velocity is normally in the range of 3 to $6 \mathrm{~m} / \mathrm{s}$. The fuel is fed with a screw at the bottom of the combustion chamber. Limestone and other bed materials are introduced at the same place. The particle separator consists 
of a hot cyclone and the separated bed material is returned to the combustion chamber through a return leg.

In preparation for the present tests a secondary air distribution system was mounted on the combustion chamber. The system consists of four registers, called over-fire air registers (OFA 1 to 4 ). Secondary air can be supplied to one or more registers according to the test requirements. Instead of air, recirculated fluegas can be used. Recirculated flue-gas can also be supplied to the bottom of the combustion chamber and to a separate register located at the inlet to the cyclone (OFA 5). The flue-gas recirculation is used whenever necessary to control the temperature of the bed independent of the air supply. The use of flue-gas recirculation affects the flow in the combustion chamber and it decreases the oxygen concentration somewhat. However, the increase in fluidizing velocity as well as the dilution of oxygen are deemed to be of secondary importance for the NO emission. Flue-gas recirculation is employed to reduce the formation of thermal $\mathrm{NO}_{x}$ in flame combustion where it is of primary importance. This effect is absent in fluidized bed combustion.

The (total) excess air ratio of the boiler is. based on the measurement of the oxygen concentration of the flue gases in a position where the combustion is finished, but as close as possible to the combustion chamber. The remaining gas analyses, including an additional oxygen analysis, are taken after the flue gas filter. The excess air at the bottom zone of the combustion chamber is expressed as primary air stoichiometry. This quantity is calculated from the air and fuel flows supplied to the bottom zone of the combustion chamber.

\section{THE FUEL AND BED MATERIAL}

The fuel is a North American (Pennsylvanian) coal, crushed to less than $8 \mathrm{~mm}$ with $40 \%$ smaller than $1 \mathrm{~mm}$ and a mass mean size of $2.0 \mathrm{~mm}$. Other characteristics are given in Table 1 .

TABLE 1 The Coal Characteristics

TABLE 2 Composition of Ash and Bed

\begin{tabular}{ll}
\hline Ash (as received) & 0.08 \\
Moisture (as received) & 0.10 \\
Ultimate analysis & \\
Carbon & 0.83 \\
Hydrogen & 0.05 \\
Oxygen & 0.08 \\
Nitrogen & 0.017 \\
Sulphur & 0.022 \\
Volatile matter (a.m.f.) & 0.39 \\
\hline
\end{tabular}

\begin{tabular}{lccc}
\hline & $\begin{array}{l}\text { Coal } \\
\text { Ash }\end{array}$ & $\begin{array}{l}\text { Bed of } \\
\text { Sand }\end{array}$ & $\begin{array}{l}\text { Bed with } \\
\text { Limestone }\end{array}$ \\
\hline $\mathrm{CaO}$ & 3.5 & 0.81 & 18.8 \\
$\mathrm{SiO}_{2}$ & 46 & 92.6 & 70.2 \\
$\mathrm{Al}_{2} \mathrm{O}_{3}$ & 26 & 3.65 & 2.57 \\
$\mathrm{Fe}_{2} \mathrm{O}_{3}$ & 16 & 1.56 & 1.08 \\
$\mathrm{MgO}_{\mathrm{MnO}}$ & 0.75 & $\star$ & $\star$ \\
$\mathrm{K}_{2} \mathrm{O}$ & $\star$ & $\star$ & $\star$ \\
$\mathrm{Na}_{2} \mathrm{O}$ & 0.5 & $\star$ & $\star$ \\
$\mathrm{P}$ & 0.6 & 0.08 & $\star$ \\
$\mathrm{SO}_{3}$ & 2.5 & $\star$ & 0.08 \\
\hline
\end{tabular}

The limestone is of Swedish origin of the name of Ignaberga. The stone is doublescreened, 0.2 to $1.5 \mathrm{~mm}$. The sand is silica sand with a size of $0.35 \mathrm{~mm}$. The composition of the fuel ash and of the bed is given in Table 2 .

\section{PRIMARY RESULTS}

The results from the measurements in the $8 \mathrm{MW}$ boiler are presented below. They are to a certain extent compared with results from the $40 \mathrm{MW}$ CFBB in Nyköping, Leckner and Amand (1987), and with general experience from SFBB's. 


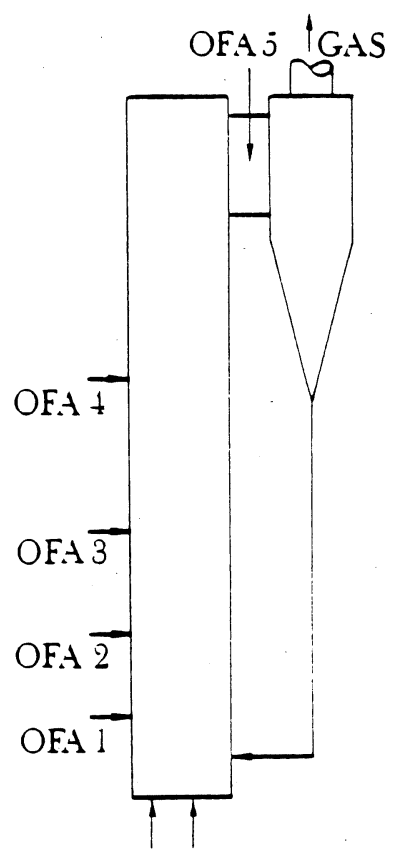

AIR FLLE GAS

Fig. 1.

The 8 MW boiler. Five secondary air registers (OverFireAir = OFA) are indicated. Recirculated flue gas can be added through the OFA registers and at the bottom of the combustion chamber.

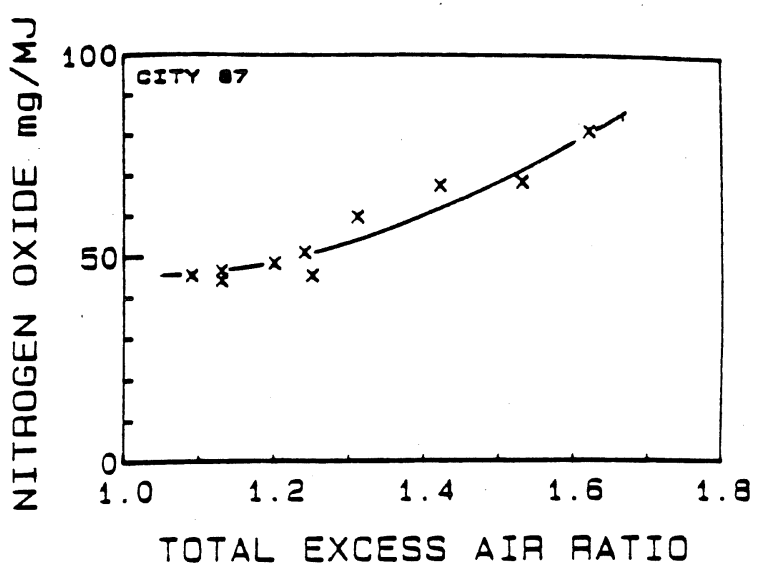

Fig. 2 .

The NO emission as a function of the total excess-air ratio. Sand bed.

Bed temperature $\quad 842 \pm 5^{\circ} \mathrm{C}$

Primary

stoichiometry $\quad 0.75 \pm 0.05$

Air register OFA 1

\section{Air Supply and Air Distribution}

The influence of the total excess-air ratio. on the No emission when the other most important influencing factors are kept constant is shown in Fig. 2.

The inclination of the curve in Fig. 2 is the same as that observed in the CFBB in Nyköping but less than the inclination of similar relationships registered in SFBB's. In contrast to previous observations the curve of Fig. 2 levels out at low excess air ratios.

The NO emission from the 8 MW CFBB with a sand bed is hardly affected by the primary air stoichiometry, Fig. 3. This is in contrast to the SFBB where staged air supply causes a considerable decrease in the NO emission. An example showing a decrease of 40 to $50 \%$ in an SFBB is given by Leckner and Amand (1987).

It is also known from previous experience with SFBB's that an increase in the distance between the dense bed and the secondary air register leads to a decrease in the NO emission, Tatebayashi and co-workers (1980). In the 8 MW boiler the secondary air could be introduced in one OFA register after another, leaving only some cooling air in the OFA 1 register. The result shown in Fig. 4 is in obvious contrast to the experience from SFBB's. The addition of the secondary air in the higher registers OFA 2 to 4 only led to insignificant improvements in the NO emission.

The general impression is that the CFBB with a sand bed is not particularly sensitive to the air supply nor to the air distribution. A similar result was obtained by Hirama and co-workers (1987). 


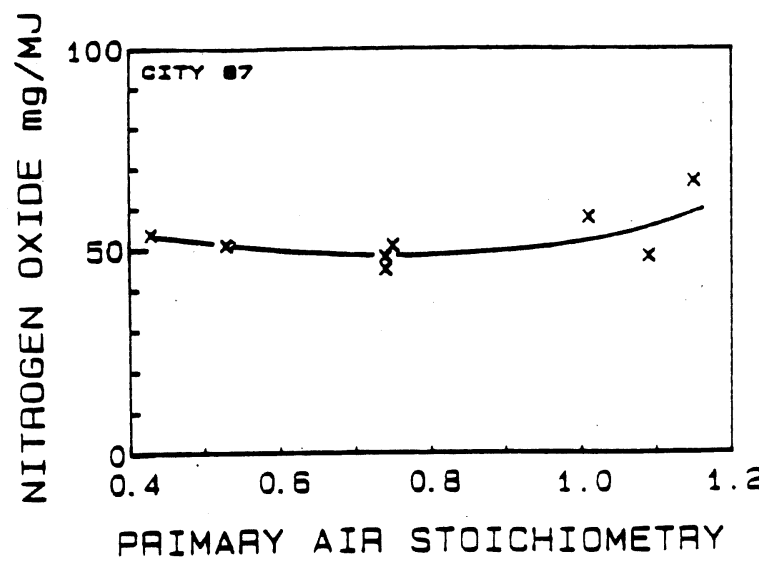

Fig. 3 .

The NO emission at different primary air stoichiometries. Sand bed.

$\begin{array}{ll}\text { Excess air ratio } & 1.22 \pm 0.03 \\ \text { Bed temperature } & 846 \pm 5^{\circ} \mathrm{C} \\ \text { Air register } & \text { OFA } 1\end{array}$

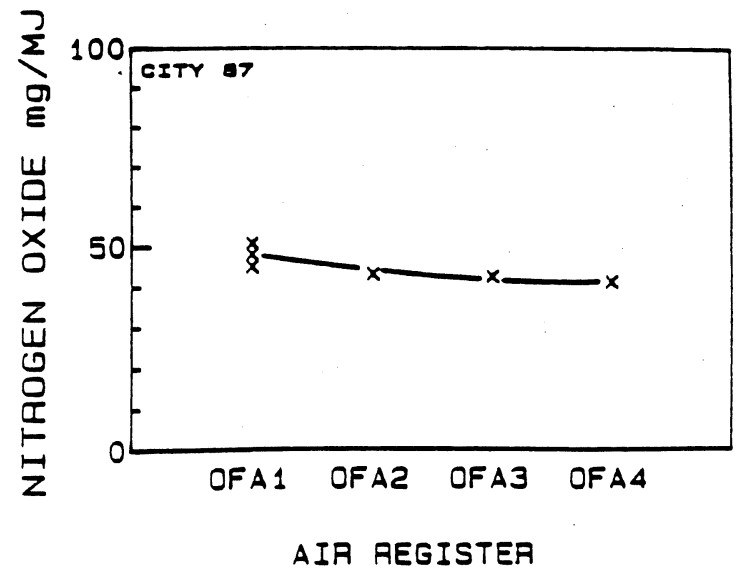

Fig. 4.

The NO emission when the secondary air is introduced through one of the four registers. Sand bed.

Bed temperature $\quad 843 \pm 2{ }^{\circ} \mathrm{C}$

Primary

stoichiometry $\quad 0.72 \pm 0.03$

Excess air ratio $1.22 \pm 0.02$

\section{Bed Temperature}

The influence of the bed temperature on the NO emission at constant air supply and air distribution is compared with the corresponding data from the $40 \mathrm{MW}$ CFBB in Nyköping in Fig. 5.

At temperatures above $850^{\circ} \mathrm{C}$, the inclination of the curves is about the same as that of the SFBB, Leckner and Amand (1987). At lower temperatures both curves level out, but at different NO emission levels.

\section{Limestone Addition}

In the Nyköping CFBB the addition of limestone increased the NO emission compared with runs when only silica sand and ash were used as bed material. Extremely large emissions were recorded at excessive feed rates of limestone.

Similar results were obtained in the $8 \mathrm{MW}$ boiler, but the difference between a sand bed and a bed with limestone addition is not as large as in Nyköping even at the high limestone feed rate of $\mathrm{Ca} / \mathrm{S} \simeq 5$.

Fig. 2 to 4 show that the NO emissions from the sand bed are quite insensitive to modifications in the air supply. Fig. 6 shows the result of a step change of $60 \%$ in the secondary air feed-rate in a run with a sand bed. In order to keep the temperature constant the flue gas recirculation was decreased at the same time. In spite of the step change, the total excess-air ratio changes only slowly, as does the NO emission, which follows the excess-air ratio based on the $\mathrm{O}_{2} \mathrm{con}^{-}$ centration in the flue gas, rather than following the air supply. In the lime bed (sand bed with limestone addition) the situation is quite different. Changes in the air feed-rate are followed by instantaneous responses in the No emission.

The tests are in progress and all results are not available. It was considered particularly interesting to show that the negative effect of 1 imestone addition could be counteracted by adjustment of the air supply. Thus, the tests shown in Fig. 4 were repeated with the lime bed at a 1 imestone feed rate of $\mathrm{Ca} / \mathrm{S} \simeq 5$. 


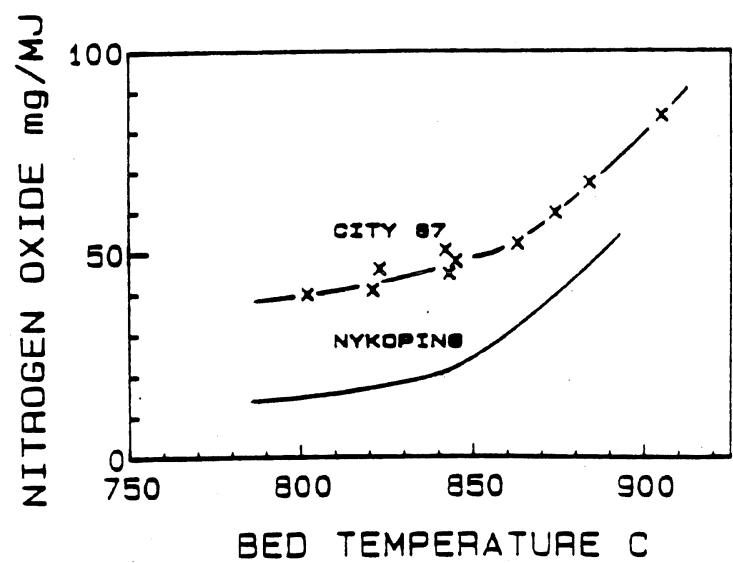

Fig. 5 .

The NO emissions from the $40 \mathrm{MW}$ CFBB in Nyköping compared with the $8 \mathrm{MW}$ CFBB at Cityvarvet as a function of bed temperature. Sand beds.

$$
40 \mathrm{MW} \quad 8 \mathrm{MW}
$$

Excess air

$\begin{array}{lcc}\text { ratio } & 1.20 & 1.22 \pm 0.03 \\ \text { Primary } & & \\ \text { stoichio- } & & \\ \text { metry } & \text { varying } & 0.74 \pm 0.04 \\ \text { Register } & \text { OFA } 1 & \text { OFA } 1\end{array}$

Fig. 7 .

The NO emission when the secondary air is introduced through one of the four air registers. Comparison between a sand bed (Fig. 4) and a bed with limestone addition, $\mathrm{Ca} / \mathrm{S} \approx 5$. Note that the total excess air ratios are somewhat different.

$$
\text { Sand bed Lime bed }
$$

\begin{tabular}{|c|c|c|}
\hline ture & $843 \pm 2^{\circ} \mathrm{C}$ & $840 \pm 4^{\circ} \mathrm{C}$ \\
\hline $\begin{array}{l}\text { Primary } \\
\text { stoichiometry }\end{array}$ & $0.76 \pm 0.03$ & $0.73 \pm 0.06$ \\
\hline $\begin{array}{l}\text { Excess air } \\
\text { ratio }\end{array}$ & $1.22 \pm 0.02$ & $1.40 \pm 0.05$ \\
\hline
\end{tabular}

Bed tempera-

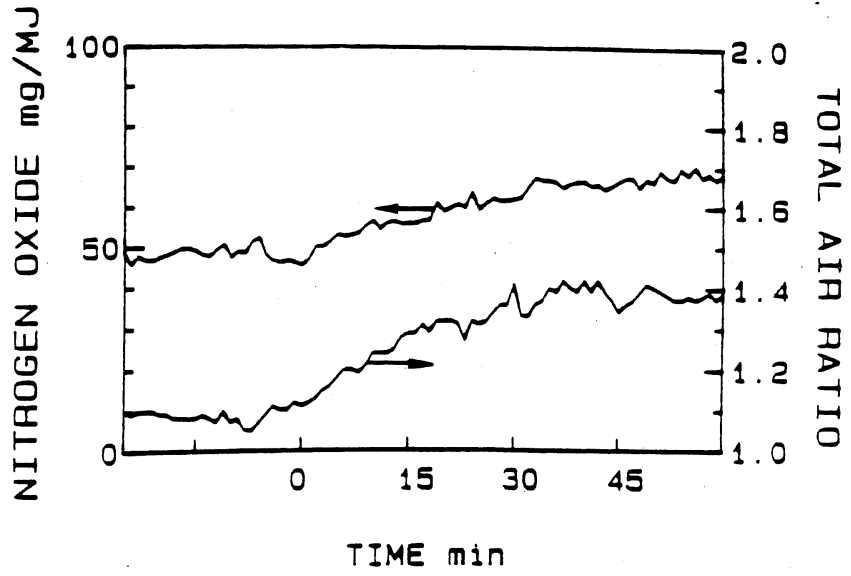

Fig. 6 .

The influence of a step change in the air supply on the No emission and the total excess air ratio measured from the $\mathrm{O}_{2} \mathrm{con}^{-}$ centration. The bed temperature is constant $845^{\circ} \mathrm{C}$. Sand bed.

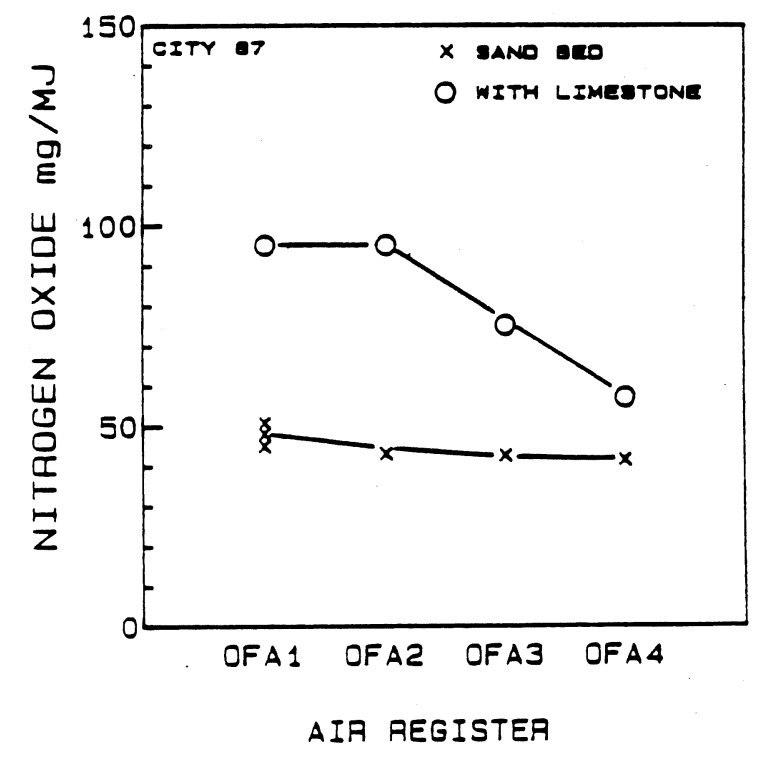

Fig. 7 indicates that the effect of this large addition of limestone can be more or less removed by arranging the air supply in a suitable way.

DISCUSSION OF RESULTS AND COMPLEMENTARY TESTS

Fundamental Knowledge

Furusawa and co-workers (1985) have summarized reactions concerned in the conversion of the fuel nitrogen to either nitrogen oxide or to nitrogen, Table 3 . 


\begin{tabular}{|c|c|c|c|}
\hline Reaction & Gas-solid & $\begin{array}{l}\text { Solids } \\
\text { catalyzed }\end{array}$ & Gas phase \\
\hline 1. Char + NO & 0 & - & - \\
\hline $\begin{array}{l}\text { 2. Reduction of } \mathrm{NO} \\
\text { by } \mathrm{CO} \text { and } \mathrm{H}_{2}\end{array}$ & - & 0 & - \\
\hline 3. Decomposition of $\mathrm{NH}_{3}$ & - & 0 & - \\
\hline $\begin{array}{l}\text { 4. Reduction of } \mathrm{NO} \text { by } \mathrm{NH}_{3} \\
\text { Absence of oxygen } \\
\text { Presence of oxygen }\end{array}$ & - & $\begin{array}{l}0 \\
0\end{array}$ & $\overline{0}$ \\
\hline 5. Oxidation of $\mathrm{NH}_{3}$ & - & 0 & 0 \\
\hline \multicolumn{4}{|c|}{$\begin{array}{l}0 \text { Possible reaction at } 700 \text { to } 900^{\circ} \mathrm{C} \\
\text { - No significant reaction at } 700 \text { to } 900^{\circ} \mathrm{C}\end{array}$} \\
\hline
\end{tabular}

The volatile nitrogeneous compounds evolving from the thermal decomposition of the fuel are approximated by ammonia. The solids known to be most active as catalysts are char and lime. Silica sand is not deemed to be active, but it contributes to the decomposition of $\mathrm{NH}_{3}$ as shown by Hirama and co-workers (1983). The possible contribution of various components of fuel ashes as catalysts has not yet been studied.

\section{The Role of Char}

Statement 1. In a CFBB with a bed of silica sand, as well as in the bed of an $\mathrm{SFBB}$, char is the principal agent for the reduction of nitrogen oxide (Reactions 1 and 2 of Table 3 ).

Discussion: The amount of the reaction-surface of the char in the bed, at a given heat release rate and a given fuel, depends on the bed temperature and on the air supply to the bed. These factors also influence the content of carbon monoxide in the bed. Thus, the inclined parts of Fig. 2 and 5 may be explained as being mostly the result of the char content of the bed although the rates of other reactions are also affected by the temperature. The levelling out at low temperatures and excess air ratios remains to be explained, as well as the difference in emission level between the two CFBB's.

Fig. 6 gives an example of the dominating role of char. The step change in the air supply is followed by a gradual readjustment of the content of char in the bed to a new equilibrium concentration of char. The NO emission follows proportionally to the char content during this half-hour transition. The transition NO values agree approximately with values recorded at equilibrium tests, Fig. 2 .

The influences of the contents of char and oxygen in the bed are separated at a short interruption of the fuel feed. The oxygen content then increases instantaneously but the char content remains about the same during the short period of time. The NO emission is not affected, which supports the conclusion that the oxygen concentration itself is of minor importance in a sand bed (but not in a bed with limestone addition, see below!)

The difference in experience with staged combustion in an SFBB and this CFBB can also be explained as being mostly due to the combustion of char. An airdeficient zone is more easily created in the dense bed of an SFBB where most of the fuel burns, than in a CFBB where the fuel is contained in the entire combustion chamber. The results of Fig. 3 and 4 can be seen as a consequence of the fact that the actual stoichiometry in the bottom section of the combustion 
chamber is quite different from that expressed by means of the feed flows of air and fuel. Coarser fuel and low bottom zone velocities may improve the No reduction by staged air supply in a CFBB.

\section{The Role of Volatiles}

Statement 2. Ammonia is not active in the combustion chamber of a CFBB with a bed of silica sand.

Discussion: If the contact time is sufficient, ammonia decomposes mostly to nitrogen and hydrogen according to reaction 3 of Table 3 in a bed of silica sand. For that reason ammonia does not significantly influence the NO emission from a CFBB with a sand bed. This conclusion is supported by the results of Hirama and co-workers (1987) who measured the decay of NO along the height of their circulating bed reactor and at the same time confirmed that the amount of $\mathrm{NH}_{3}$ present was very small.

In order to support this conclusion further, ammonia was injected together with recirculated flue-gas through the OFA registers. The momentum of the jets was sufficient for a thorough mixing with the bed medium. The effect of the ammonia injection on the NO emission was negligible in the registers OFA 1 to OFA 4. Only in the register at the inlet to the cyclone (OFA 5) there was a small reduction of the NO emission but also a noticeable escape of $\mathrm{NH}_{3}$. A similar result is obtained at the addition of ammonia to the dense bed of an SFBB. At the injection in the freeboard above the bed of an SFBB, there is, on the other hand, a reasonable reduction of the NO emission as a consequence of the ammonia injection. If ammonia is to be used to decrease the No emission from a CFBB with a bed of sand, it must be injected in the particle-free gas stream after the particle separator.

Furusawa and co-workers (1978) have shown that more ammonia leaves the dense bed of an SFBB when the bed excess-air ratio decreases. The ammonia may contribute to the reduction of $N O$ in the freeboard. This contribution of reaction 4, Table 3, is evidently not significant in the CFBB, which may explain why the dependence on the total excess air ratio is stronger in an SFBB than in a CFBB.

\section{The Role of Limestone Addition}

Statement 3. When the circulating bed contains calcium oxide, the ammonia released at the devolatilisation of the fuel is oxidized and the emission of No increases (reaction 5, Table 3 ).

Discussion: Several laboratory investigations, Hirama and co-workers (1983), Furusawa and co-workers (1985), Lee and co-workers (1985, 1987), have shown the influence of calcium oxide on the oxidation of ammonia. In a bed to which limestone is added in such a way that the calcined limestone comes into contact with oxygen, the oxidation of ammonia is a very likely explanation of the increase in the NO emission observed at limestone addition to a CFBB. Consequently, this effect could be mitigated in two ways:

1. By adding the secondary air as late as possible, that is, after the volatiles have burned.

2. By avoiding excessive limestone addition, that is, a sulphur retention of 80 to $90 \%$ would be a suitable limit.

With the fuel distributed over the entire combustion chamber, the present tests have not been ideal to prove the first point. However, most of the devolatilisa- 
tion occurs in the lower parts of the combustion chamber and Fig. 7 shows that it is possible to influence the NO emission in a lime bed with delayed air addition.

\section{CONCLUSIONS}

In a circulating bed of silica sand, char is the principal agent for the reduction of nitrogen oxide. The role of volatiles is not significant. Most features observed can be qualitatively explained as a consequence of the presence of char.

In a circulating bed with limestone addition, the oxidation of nitrogen containing volatiles causes an increased emission of nitrogen oxide. This effect can be mitigated by avoiding excess addition of limestone in relation to the sulphur content of the fuel or by arranging the air supply in a suitable way, thus decreasing the oxidation of ammonia.

\section{ACKNOWLEDGEMENTS}

This work has been financially supported by the National Swedish Energy Administration and Götaverken Energy.

\section{REFERENCES}

Furusawa, T., T. Honda, J. Takano, and D. Kunii (1978). Nitric oxide reduction in an experimental fluidized-bed coal combustor. In J.F. Davidson and D.L. Keairns (Ed.), Fluidization, Proc. of the Second Engineering Foundation Conf., Cambridge.

Furusawa, T., M. Tsujimura, K. Yasunaga, and T. Kojima (1985). Fate of fuel bond nitrogen within fluidized bed combustor under staged air firing. The 8 th Int. Conf. on Fluidized Bed Combustion, Houston, Pp 1095-1104.

Hirama, T., M. Tomita, M. Horio, T. Chiba, and H. Kobayashi (1983). A two-stage fluidized-bed coal combustor for effective reduction of $\mathrm{NO}_{x}$ emission. The 4 th Int. Conf. on Fluidization, Kashikojima, pp 467-474.

Hirama, T., H. Takeuchi, and M. Horio (1987). Nitric oxide emission from circulating fluidized-bed coal combustion. The 9 th Int. Conf. on Fluidized Bed Combustion, Boston, Pp 898-905.

Leckner, B., and L-E. Åmand (1987). Emissions from a circulating and a stationary fluidized bed boiler - a comparison. The 9 th Int. Conf. on Fluidized Bed Combustion, Boston, PP 891-897.

Lee, Y. Y., A. Sekthira, and C. M. Wong (1985). The effects of calcined limestones on the $\mathrm{NH}_{3}-\mathrm{NO}-\mathrm{O}_{2}$ reaction. The 8 th Int. Conf. on Fluidized Bed Combustion, Houston, PP 1208-1218.

Lee, Y. Y., S. M. S. Soares, and A. Sekthira (1987). The effects of sulphated limestones on the $\mathrm{NH}_{3}-\mathrm{NO}-\mathrm{O}_{2}$ reaction. The 9 th Int. Conf. on Fluidized Bed Combustion, Boston, pP 1184-1187.

Tatebayashi, J., Y. Okada, K. Yano, and S. Ikeda (1980). Simultaneous $\mathrm{NO}_{\mathrm{X}}$ and $\mathrm{SO}_{2}$ emission reduction with fluidized bed combustion. The 6 th Int. Conf. on Fluidized Bed Combustion, Atlanta, pp 986-995. 